\title{
Integration of MOOCs Online Courses into Open and Distance Teacher Education in India
}

\author{
Mahesh Paswan ${ }^{1}$ and Shilpi Kumari2*
}

${ }^{1}$ Student, M.ED. (2017-19), Mahatma Gandhi Antarrashtriya Hindi Vishwavidyalaya, Wardha, Maharashtra, India

${ }^{2}$ Assistant Professor, Mahatma Gandhi Antarrashtriya Hindi Vishwavidyalaya, Wardha, Maharashtra, India

*Corresponding author: shilpik27@yahoo.com

Received: $15-03-2020$

Revised: $21-06-2020$

Accepted: 29-07-2020

\begin{abstract}
The present research was focused on studying the infrastructure facilities and human resource available for conducting NIOS D.El.Ed. Blended MOOCs Programme (2017-19), analysing its mechanism as well as studying the changes in the ODL D.El.Ed. programme due to integration of MOOCs online courses. The data were collected through structured interview with the coordinator of NIOS D.El.Ed. programme (2017-2019) at NIOS headquarter, coordinators of the regional centres and the students (in-service primary school teachers) and counsellors of the regional centres included in the sample. It was found that NIOS D.El.ED. Blended MOOCs Programme (2017-19) was conducted through direct counselling sessions, personal contact programme, school-based activities, workshops for practical work, SWAYAM MOOCs courses and SWAYAM PRABHA audio-video lessons. Many students of D.El.Ed. programme felt the online courses available on SWAYAM portalas an extra work and waste of time. Some of them opined that the course material on SWAYAM should have also been developed in as many regional languages of India as possible so that it could easily outreach Indian villages. The students, coordinators and counsellors, however, appreciated that SAWAYM is making rapid inroads into the near future in the field of open and distance teacher education. They were also of the view point that SWAYAM platform should be developed as Web 2.0 platform where students/participants would also have the opportunity to contribute to the development of quality course material.
\end{abstract}

Keywords: ODL system, MOOCs, Blended MOOCs, SWAYAM, SWAYAM PRABHA

The Open and Distance Learning (ODL) system is an education system in which the students are not required to be present in one place and at the same time and this system is flexible in relation to the procedures and available time and access is granted without compromising with quality principles. The institutions like National Open University (IGNOU) and State Open University institutions are involved in imparting education in ODL mode. There are also correspondence course institutes (CCI) in traditional two-method universities. The ODL system proves to be very important for continuing education and skill upgradation of in-service personnel and for providing relevant quality education to the aspirants living in deprived and remote places.
In Ninety sixties in India, the educational policies of the Government of India were oriented towards distance education. The requirements for expansion and dissemination of higher education made the Planning Commission think in this direction, which led to the launch of evening colleges, correspondence courses, open universities, etc. in order to increase the opportunity of higher education. Gradually, information technology was started being used in the field of distance higher education in India. At the present time, a round of online courses have

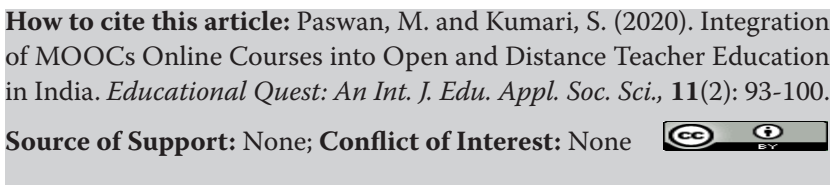
of MOOCs Online Courses into Open and Distance Teacher Education in India. Educational Quest: An Int. J. Edu. Appl. Soc. Sci., 11(2): 93-100. Source of Support: None; Conflict of Interest: None (c) $\oplus$ 
been started. The MOOCs online courses are a new initiative in this direction. The MOOCs online courses are being run by the Ministry of Education, Government of India on its SWAYAM platform and are also being enriched through SWAYAM PRABHA of Government of India itself. The objective of this effort is to reach out to the most disadvantaged aspirants and to provide the best teaching-learning resources to all. SWAYAM is intended to provide education to the students who are untouched by the digital revolution and unable to join the mainstream of education.

\section{Information Technology in Distance Education}

The role of information technology in Open Universities is self-evident that some unprecedented changes can be seen in the present generation of distance education. Today, possibilities are being explored in distance education. The implications of information technology have also been explored to make distance education a success and efforts are being made to maintain the quality and utility of distance education by making full use of it.

Development of open and distance education and the development of free educational resources are essential to fulfil the goals of expansion, excellence and development in higher education. The number of students taking admission into open and distance education in higher education is increasing fast. The National Knowledge Commission recommends that ICT-based systems should be developed in distance education under which feedback system should be improved. It also recommends developing webbased shared free resources, setting up credit banks and providing national testing services.

By looking at the present situation of distance education, we find that the need for an open university has been felt in most developed countries all over the world. The United States has been the uncontested leader in online education.

The $21^{\text {st }}$ century has started as an era of information technology. Today, the preferences of politicians, planners, administrators, businessmen, scientists, researchers, media persons and visionary persons are towards use of information technology in distance education. In India, a lot of efforts are being made to incorporate information technology in distance education. In India distance education promotes integration of information, communication and technology and online education is also being provided. It has also been imagined to create a virtual university so that any student can complete his studies through computer and internet sitting at home.

In the field of distance education, there are many media of information and communication technology, which are being used such as radio broadcasting, Doordarshan, audio-visuals, electronic mail, computer network, fax, teleconferencing etc.

The role of information technology in Open University is self-evident as it is also implemented by radio and television. Internet was started in 1995.

Gyanadasharn has been broadcasting educational programs since January 2000 whereas Gyanvani has been broadcasting educational programs since $7^{\text {th }}$ November 2001.

On 27 October 2009, IGNOU signed an agreement with Sweden's telecommunications company Ericsson to provide online education through third generation (3G) mobile phone technology. If fax and teleconferencing are used in full, then the expenditure burden on distance education can also be reduced compared to formal education and the challenges of education can be solved.

\section{Open Educational Resources (OERs) in India}

National OER Repository, NCERT and NPTEL (National Programme on Technology Enhanced Learning) have made study materials open and share by SA licence under CC. Karnataka OER Wiki IT for Change is working with the teachers to explain OER's role in preparing lesson plan in Karnataka state and it is presented at KOER. (www. tess-india.edu.in)

\section{MOOCs (Massive Open Online Courses) or SPOCs (Small Private Online Courses)}

The trend of online colleges has increased at this time. With its help, people sitting at home or away have also started learning. Students get new opportunities and the people those who work get a chance to study further. These opportunities for online learning are of two types 1. Massive Open Online Courses 2. Small Private Online Courses. 
The SPOCs or MOOCs give the students the facility of university-level online classes with all the necessary materials. SPOC takes less students especially it is meant for participation of 20-30 students.

This course is used for the employees, the employees are given training at a low cost along with providing learning materials to them.

MOOCis a web-based platform that provides unlimited students around the world with the potential for distance education with the best resources worldwide. It was founded back in 2008 and in 2012 has gained momentum as a popular learning tool (Malik, 2015).

\section{MOOCs in Indian Higher Education}

The MOOCs community has interactive sessions and forums among students, professors and teaching assistants (TA) with course materials and video lectures.

There are students across the country who are talented and they just want a chance. MOOC is a great option for students for quality education irrespective of the institutes they are associated with and for the students who do not have access to the best schools and colleges in India. EDX has a partnership with institutions like IIT Mumbai, IIT Bangalore and BITS Pilani in India. The courses of these institutions are now available on EDX. It has tied up with India's leading employment solution company, Aspiring Minds to provide employment through MOOCs. Given the state of digital technology in India, MOOCs may be a better option.www.iimbx.edu.in

Recognizing the huge skill gap among the Indian youth, the central government has started various programmes in the direction of development to make India a centre of skilled talent.

Students and teachers work together to create an online bridge of resources that is easily available to us. Recently, the trend of online classes in the field of teacher education has increased. With the help of online courses/classes people sitting far away have started learning and teaching, students start getting new opportunities. The Government of India has started providing teacher education through D.El.Ed which is a Blended MOOCs programme, education is being imparted through both MOOCs and ODL medium. The objective of elementary teachereducation programme through Open and Distance Education System is to develop professional skills and interests of teachers serving in elementary schools and also enhance the effectiveness of teaching-learning processes. Therefore, NIOS D.EL. Ed programme of Government of India, which is Blended MOOCs, is now completely free. Nobody has to pay any kind of fees for enrolment on SWAYAM platform, but if anyone has not registered into the course, they can't read the study materials.

\section{Rationale of the Study}

In the present research, an attempt has been made to find out what changes have taken place in Open and Distance Teacher Education in India through integration of MOOCs online courses. Most of the research studies in the field of open and distance learning and correspondence education have aimed at studying the available infrastructural facilities and human resource in educational institutions offering education in ODL and correspondence mode (Rathore, 1991; Dhaneshwar, 2011; Naidu, 2000). Many research studies point to the integration of ICT into open and distance education and the increasing intervention of online media (Kanchan, 1996; Biswal et al. 2002; Tomadoki et al. 2008; Wang \& Quiao, 2009; McAuley et al. 2010). In order to increase the access to quality education and to encourage ICT integrated education, the Government of India has been offering a number of MOOCs courses since the year 2017 through its SWAYAM portal, which are being integrated with the regular courses of many institutes. The initiative has also been taken in the field of teacher education in the form of NIOS D.El.ED programme (2017-19). It was conducted as a blended MOOCs programme, in which open and distance teacher education programme was integrated with MOOCs Courses through SWAYAM platform. In addition, an attempt was also made to enrich the programme through Educational TV -SWAYAM PRABHA. In the present research, a case-study of NIOS D.El. Ed. Blended MOOCs Programme (2017-19) was undertaken by the researcher emphasizing on the uses of online media in teacher education and the need of integration of MOOCs courses. 


\section{Statement of the Problem}

In an effort to enhance the effectiveness and quality of open and distance teacher education programme, a blending of Open and Distance Learning (ODL) system and MOOCs courses is being adopted. The D.El.Ed. programme of NIOS is an initiative in this direction. There are very few studies on online courses in India that too in teacher education. Therefore, as an effort in this direction the present research study was conducted to analyse NIOS D.EL.Ed. Blended MOOCs programme.

\section{Research Questions}

1. How much adequate were the infrastructural facilities and human resource available to conduct the NIOS D.El.Ed. Blended MOOCs Programme (2017-19)?

2. How was the mechanism of NIOS D.El.Ed. Blended MOOCs Programme (2017-19)?

4. What was the role of the MOOCs courses run through SWAYAM platform in conducting NIOS D.El.Ed. Blended MOOCs Programme (2017-19)?

5. What was the role of the audio-video lessons broadcasted through SWAYAM PRABHA channel in conducting NIOS D.El. Ed. Blended MOOCs Programme (2017-19)?

6. What kind of changes have occurred in ODL D.El.Ed. Programme through integration of MOOCs online courses?

\section{Research Objectives}

1. To study the infrastructure facilities and human resource available for conducting NIOS D.El.Ed. Blended MOOCs Programme (2017-19).

2. To study the mechanism of NIOSD.El.Ed. Blended MOOCs programme.

3. To study the perceptions of the students (in-service primary school teachers)towards the role of MOOCs courses run through SWAYAM in conducting NIOS D.EL.Ed. Blended MOOCs Programme.

4. To study the perceptions of the students (in-service primary school teachers) towards the role of audio-video lessons broadcasted through SWAYAM PRABHA channel in conducting NIOS D.El.Ed. Blended MOOCs Programme.

5. To study the changes in the ODL D.El.Ed. programme due to integration of MOOCs online courses.

\section{Operational Definitions}

MOOCs: It is a web-based platform, a massive open online course which provides quality education to an unlimited number of students all over the world with the potential for distance education with the best institutions around the world.

Open and Distance Learning (ODL): Open and distance learning is open and accessible to everyone. It provides candidates the opportunity of education irrespective of any age, caste, economic status, class, handicap, crime, etc., which cannot be in a normal school or university or any other educational institutions. There is flexibility in presentation of open and distance learning courses. It frees the learners from the constraints of time (asynchronous learning) and place (distance learning). It provides opportunities for learners to have a high degree of autonomy and flexible learning. This flexibility relates to course content, which anyone can structure. Its implementation is flexible with respect to location, medium and time, process speed and forms of available resources.

ODL Diploma in Elementary Teacher Education (D.El.Ed.): The objective of the Elementary Teacher Education Programme through Open and Distance Learning System is to develop the professional skills and aptitudes of teachers serving in elementary level schools and also enhance the effectiveness of the teaching-learning process. D.El.Ed. programme is offered through open and distance learning method and provides a wide opportunity for elementary school teachers to be trained professionally without disrupting their regular work of teaching through use of self-instructional materials and online resources. It promotes development of professional skills and critical understanding of school education among them and encourages them becoming a good teacher. In the field of teacher education, a number of online courses are being offered by various educational institutions through SWAYAM portal of the Ministry of Education, Government of India. In the present research, under elementary teacher education,NIOS D.El.Ed. Blended MOOCs 
Programme (2017-19) was included. Its MOOCs courses were run through SWAYAM platform and was enriched by SWAYAM PRABHA channel.

Blended MOOCs Programme: In the present research NIOSD.El.Ed. Blended MOOCs Programme (201719) was studied. This was a programme which was conducted in an integrated form through both ODL and MOOCs online courses. MOOCs courses were conducted through SWAYAM online platform. These MOOCs courses were enriched through audio-visual lessons of SWAYAM PRABHA Educational TV channel. The course material was also provided to the participants in the form of offline medium-printed material, CDs containing PDF, video lecture etc. Along with counseling sessions and workshops were also organized for practical work such as school teaching practice.

\section{Delimitations of the Study}

1. The study was delimited to Headquarter of NIOS, the Regional Centres in Delhi and Regional Centres in Darbhanga District of Bihar.

2. The study was delimited to Open and Distance Learning System.

3. The study was delimited to elementary level of teacher education.

4. The study was delimited to NIOS D.El.Ed. Blended MOOCs Programme (2017 -2019).

\section{Research design}

The Present research is a descriptive research, in which to study the integration of MOOCs online courses into Open and Distance Teacher Education in India, NIOS D.El.Ed. Blended MOOCs programme (2017-19)was studied as a case. Field studies were conducted at NIOS Headquarter, Noida and the four regional centres selected in the sample to get an idea of the structure and functioning of NIOS D.El.Ed. programme (2017-19). Questionnaire and interview techniques of data collection were used for field studies.

\section{Population and sample}

In the present research NIOS headquarter and its regional centres were included as a population to study NIOS D.El.Ed. Blended MOOCs Programme (2017-2019). NIOS Headquarter, Noida and purposively chosen two Regional Centers (DIET, Moti Bagh \& DIET, RK Puram) located in Delhi and two Regional Centers of Darbhanga district of Bihar (CRC Middle School, Jayantipur and BRC, Birol) were selected as the sample.

The data were collected through structured interview with the coordinator of NIOS D.El.Ed. programme (2017-2019) at NIOS headquarter, coordinators of the regional centres and the students (in-service primary school teachers) and counsellors of regional centres included in the sample. According to the need of the research, 20 students (in-service primary school teachers) and 8 counsellors were selected as participants of the study. Dr. Gaurav Singh, Assistant Professor, IGNOU, New Delhi, associated with the development of audio-video lessons broadcasted by Swayam Prabha channel to enrich D.El.Ed. programme, was also selected as a participant of the study.

\section{Research tools}

The researcher collected data related to NIOS D.El.Ed. programme through structured interview with the coordinator of the programme at NIOS headquarter. The data were then collected through structured interviews with the coordinators of the selected regional centres and counsellors and students of these regional centres. To collect the data related to infrastructural facilities and the human resource available for conducting NIOS D.El.Ed. programme, the information schedule was filled by the researcher himself with the help of coordinators of the regional centres. The assistance of coordinator of the D.El.Ed. programme, media consultant and counsellors was also taken for collecting information in this regard. The researcher collected data from the coordinators, counsellors and students of the regional centres of Darbhanga District through telephonic interview. The data regarding the role of SWAYAM PRABHA in the context of NIOS D.El. Ed. programme were collected through structured interview with Dr. Gaurav Singh, Asst. Professor, IGNOU.

\section{Research Findings}

During counseling sessions, the space for sitting was sufficient but during special programmes there was inconvenience of sitting. This problem 
was found to be common in both Delhi and Darabhaga centres.

The students of Delhi centres had almost all types of facilities but the students of Darbhanga centres did not have many facilities such as drinking water, toilet facility, use of ICT equipment in the classrooms, continuous electricity etc. However, both the centres did not have a library and ICT room.

$\square$ During the counseling sessions the regular employees of D.El.Ed. programme used to do the work of cleanliness at the Regional Centres of Delhi. Cleanliness was also maintained at Darbhanga centres, but there were less number of cleaners.

During the counseling sessions, the teaching work was carried out according to the syllabus in the classes. Sessional group work, lesson plan, micro-teaching etc. were also discussed. How to teach the students according to their mental ability and aptitude was greatly emphasized and practiced. Education of Information and Communication Technology was also imparted in the classes and the subjects were also taught using PPT.

There was a media lab at the headquarter of NIOS, Noida for recording video lessons for SWAYAM MOOCs courses and SWAYAM PRABHA. Several modern equipments were available in the PCR room and the camera man and subject specialist were instructed during recording of audio-video lessons through the mirror wall. A variety of software and hardware were used for editing audio-video. The quality of the audio-video lessons was checked in the media library, after which it was sent for broadcasting to the media house.

$\square$ For the practice of school-based activities, a 12-day workshop was organized once every year throughout the programme. Subject experts were invited from outside, in which different types of activities were practiced such as preparing teaching-learning materials, preparing blue print based question papers, preparing lesson plans, practice of teaching skills etc. The problems of faced by the students (in-service primary school teachers) were also discussed during the workshop.
Personal contact program was also organized. It had a duration of 10 days, it was held twice a year. The purpose of this program was to assist the students (in-service primary school teachers) and discuss solutions to the problems encountered by them during school teaching. The students also discussed their problems with their peer.

Many types of courses are run on SWAYAM. It is focused on attainment of three important basic principles - access, equity and quality. For the online courses run on SWAYAM, four types of methods (audio-video lessons, course materials, self-assessment test and online discussion forum) are adopted. The text and audio-video lessons are specially prepared according to the needs of the learners. In case of MOOCs courses of NIOS D.EL.Ed programme, 4-quadrant approach was adopted. Though pursuing diploma degree, registration on the MOOCs portal itself was not compulsory, but the students(in-service primary school teachers) who registered on MOOCs had an access to high quality course material. The students could read the course material anytime and anywhere on this portal. It could also be read through NIOS D.El.Ed. App.

Under SWAYAM PRABHA, audio-video lessons can be heard and seen in many languages. Teachers from the country's best educational institutions are invited as subject experts to prepare video lessons. SWAYAM PRABHA is actually a group of 34 channels that remotely broadcast high-quality educational programs on $24 * 7$ basis. SWAYAM PRABHA uses the services of GSAT-15 satellite for broadcasting educational programmes. The content based audio-videos created under the SWAYAM platform are used for broadcasting through SWAYAM PRABHA DTH channels. It broadcasts audio-video lessons in regional languages Bangla, Telugu, Assamese etc. and the students can watch the broadcast in their own language. It can also be watched in sign language. The SWAYAM PRABHA channel can also be viewed on YouTube and mobile app. There is no restriction of time and space. These facilities were also available for broadcasting audio-video lessons related to NIOS D.El. 
Ed. Blended MOOCs programme (2017-2019) through SWAYAM PRABHA.

About 70 percent of the scholars and all the counselors said that more number of audiovideo lectures on the SWAYAM portal were available in English language. This made the students, who did not have good knowledge of English language, to face a lot of problems. About 55 percent of the students said that Hindi language used for the video lecture available in Hindi language was sophisticated. They said that easy Hindi language should have been used so that they could develop a deeper understanding of the content.

Online courses on SWAYAM portal were independent courses that were not part of a fixed curriculum. Therefore, students did not consider it necessary to actively participate in it, but the students felt that it would be a great support in imparting continuing education programme in near future. Through interview with the students included in the sample, it was found that there was very less no. of enrolment of D.El.Ed. students on SWAYAM portal and those who were enrolled also used it less because most of the study material and audio-video lessons was available in English language. About 50 percent of the students pointed that less study material was available in regional languages. It was felt necessary to develop study material in as many Indian languages as possible. It still had very little access to Indian villages. Hence, we need to strive in this direction.

As many as 70 percent students of D.El.Ed. programme were of the view point that they did not get time to study the course material available on SWAYAM portal as they were teaching in some school, they rather felt it as a waste of time and considered online courses as an extra work. The coordinators of the regional centres also expressed about the students the same. About 40 percent of the students said that gender equality was not taken care of in the audio-video lessons.

A large number of untrained teachers of primary schools have been trained by the Ministry of Education, Government of India through SWAYAM online platform with the help of NIOS. About 12 lakh untrained primary teachers have been trained through NIOS D.El. Ed. Blended MOOCs Programme which is a major achievement of its own kind.

The participants who were teaching in primary schools also got the benefits of NIOS SWAYAM PRABHA channel through You tube. Mobile JIO TV app was also used by the participants for watching SWAYAM PRABHA channel for D.El.Ed. programme. About 65 percent of the students said that they got a discount of ₹ 1500 to 2000 in their fees upon their registration on SWAYAM or subscription on the SWAYAM PRABHA channel.

SWAYAM is making rapid inroads into the near future in the field of open and distance teacher education in India. There is a need to improve the quality of audio-video lessons. Pictures and graphs should be used more in study materials, so it would be easy to understand by all types of students. The important points of PPT should be outlined in the audio-video lecture, when those points are being discussed by the subject expert, this will make the text content more comprehensible. The study materials should have in-text citation, so that the students can go there and study in detail. SWAYAM platform should be developed in the form of Web 2.0 platform where students/participants would also have the opportunity to contribute to the development of quality study material.

\section{CONCLUSIONS}

In the present research, it was found that NIOS D.El.ED. Blended MOOCs Programme (2017-19) was conducted through direct counselling sessions, personal contact programme, workshops for practical work, school-based activities, SWAYAM MOOCs courses, and SWAYAM PRABHA audiovideo lessons. The students of Delhiregional centres had almost all facilities, but the students of Darbhanga regional centres did not have many facilities. During the counseling sessions, the teaching work was carried out according to the syllabus in the classes and group work, lesson plan, micro-teaching etc. were also discussed. For recording of audio-video lessons of SWAYAM and SWAYAM PRABHA the Media Lab was in 
place. The quality of the audio-video lessons was checked in the Media Library, after which it was sent for broadcasting to the media house. A 12-day workshop was held once every year throughout the programme to practice school-based activities. A personal contact program was held twice a year for a period of 10 days to discuss solutions to the problems encountered by the students (in-service primary school teachers) during teaching in schools. For the online courses run on SWAYAM, four types of methods (video lessons, course materials, selfassessment test and online discussion forum) were adopted. The content based audio-videos created under the SWAYAM platform were also used for broadcasting through SWAYAM PRABHA DTH channels. SAWAYM is making rapid inroads into the near future in the field of open and distance teacher education in India. Therefore, there is a need to improve the quality of its audio-video lessons and other course materials and there should also be the facility for the students/participants to contribute to the development of the quality course material.

\section{References}

Biswal, A., Patel, R.C., Pushpanadham, K. and Mehta, A. 2002. A study on the use of teleconferencing for training of National Open University teachers. C.A.S.E.M.S. University of Baroda.

Dhaneshwar, H. 2012. Students support services in distance education: a Case Study. Open and Distance Learning. 18: 15-34.

Kanchan, B. 1996. Distance education programme at College and University Levels in Jammu Region: an evaluative study. Ph.D., Dissertation, 12-25, Education, Himachal Pradesh University.
Macaulay, A., Stewart, B., Cormier, D. and Siemens, G. 2010. In the open: the MOOC model for digital practice 'SSHRC' Applications. Knowledge synthesis of the Digital Economy. Retrieved from https://pdfs.semanticscholar. org/ad53/b9655587771edcf4ae028d4490a218d87ff2. pdf?_ga=2.163306684.1439671629.1566180236368241298.1566180236

Malik, S. 2015. Indian MOOCs (Massive Open Online Courses): need of the hour. International Journal of Applied Research, 1(11): 930 -932.

Naidu, G. Venkata. 2000. Study of organization and system of distance education programs of Dr. B.R. Ambedkar Open University. Ph.D. Dissertation, Education, Sri Krishnadevaraya University.

Rathore, H.C.S. 1991. A critical evaluation of the system adapted for management of teaching and learning in the existing correspondence institutes in India. National Institute of Educational Planning and Administration, New Delhi.

Tomadoki, T. Quick and Scott. 2008. Distance education technologies and media utilization in higher education. International Journal of Applied Research, pp. 1-9. Retrieved from http://itdl.org/Journal/Aug_10/Aug_10.pdf

Wang, A. and Quiao, A. 2009. An investigation of teachers' needs on using ICT in teaching and learning. International Conference on Computer Engineering and Applications IPCSIT, 2: 286-289.

Credit framework for Online Learning Courses. 2016. Retrieved from https://www.ugc.ac.in/pdfnews/4064990_ UGC-(Credit-Framework-for-Online-Learning-Coursesthrough-SWAYAM)-Regulation,-2016.pdf

Guidelines for developing Online Courses for SWAYAM. 2017. Retrieved from https://www.ugcmoocs.inflibnet.ac.in.

SWAYAM about, 2018. Retrieved from https://swayam.gov.in Open education, 2016. Retrieved from https://www.open.edu

Online education MOOCs EDX. 2015. Retrieved from https:// www.bbc.com.

IIMBx. www.iimbx.edu.in 